\title{
THE IMPLEMENTATION OF TOTAL QUALITY MANAGEMENT AT VOCATIONAL HIGH SCHOOLS IN INDONESIA
}

\author{
'Felestin; ${ }^{2)}$ Mochamad Bruri Triyono \\ ${ }^{1)}$ Madagascar; ${ }^{2)}$ Yogyakarta State University, Indonesia \\ 1)felestin.gasy@gmail.com; ${ }^{2)}$ bruritriyono@yahoo.co.id
}

\begin{abstract}
This study aims to determine the implementation of Total Quality Management (TQM) in public and private vocational high schools in the city of Yogyakarta, as well as to compare the level of implementation between public and private vocational high schools. The TQM aspects observed include infrastructures and facilities, quality of improvement, quality of teachers, quality of examination system and academic background of teachers graduated from vocational high schools. This exploratory study is descriptive in which the result can be used as an input as well as improvements in reflection of the future. These subjects were teachers and students. The primary data were collected through a questionnaire while other data were collected through observation and interviews. The data were analyzed by means of descriptive and statistics t-test. The analysis finds that TQM has been implemented by vocational schools, public and private, in the city of Yogyakarta. The Application levels differed significantly (t-value $=9.204, \mathrm{p}$-value $=$ $<0.0001$ ), where the public schools are able to implement at a very good level, while private schools are at a good level. The differences in the application of TQM occur in all measurable aspects, namely infrastructures and facilities access, quality of improvement, quality of teachers, quality of examination system and academic background of teachers graduated from vocational high schools. Specifically, on aspects of infrastructures and facilities of the access, although on average they significantly differ, categorically they are in the same level. The differences are not too large. The result of observation in the field during the study shows that the state vocational already maximally implement TQM, while in the private vocational schools, it is lower due to the limited resources in private schools.
\end{abstract}

Keywords: implementation, total quality management, vocational high schools 


\section{Introduction}

The world accelerates towards the development of sciences, including education and technology; figuring out the common globalization. Education is worthwhile since it is the base of expertise, excellence and knowledge in all sphere of discipline, as well as in social and economic context. To develop these potentials, it is necessary to plant a good quality of education system to the new generation of students from high schools. Having a good developed quality of education system from the vocational high schools, the amount of the students endowed with intelligence would probably increased. Hence, the establishment of leadership in the world would be more assured. The efficiency of the system in vocational high school depends on making available to the society dedicated, committed, devoted and professional sound team of human resources to decide the future of the Nation. This is possible only when the principles of quality management are inculcated in the system of vocational high school. In fact, it is the quality of education that shapes the longterm prosperity and wellbeing of a Nation and its people. Besides, the vast economic resources that government allocates to this sector make it imperative to ensure that education is effectively imparted at schools, universities and institutions of learning. Merely, the institutions nowadays are still faced up to the lack use of management quality and it generates low education system.

To fasten that idea up, there is one emerging philosophy of management, total quality management which is the issue of management. Total quality management has received a wide acclaim as an effective approach for achieving quality and performance enhancements in educational sphere. The common factor that will shape the strategies of vocational high schools in their attempt to satisfy various stakeholders including students, parents, industry andsociety in whole is the total quality management.

The research is a theoretical attempt to analyze the implementation of total quality management in vocational high school. It deals with issues in pertaining quality in vocational high schools and moves on to identify variables influencing the quality of vocational high schools. It also conceptualizes a model for the implementation of total quality management in vocational high schools.

The new economics grows the theories that emphasize the role of human resource as the key of economic growth and development. The World Bank's recent study of 190 countries reveals that it is the vocational high school that helps in enriching the quality of manpower. Indonesia continues to rank low in international standardized tests of student performance, even after taking socio-economic conditions into account. In 2011, Indonesia ranked 52 out of 56 countries in the Trends of International Mathematics Science Study (TIMSS). In the Program for International Student Assessment (PISA) 2006, which looks at how well 15-year-old students are prepared for life, Indonesia ranked around 50 out of 57 countries in science, reading and math with its recognition and acceptance increased day by day. In the private sector, academic institutions have started to explore the potential of total quality management application and analysis to education.

Since the total quality management is applied to the educational context, the following definitions; total quality management is not an imposition, cannot be done to us. For total quality management to work, an institution must itself want to introduce it. It is not inspection. It is always about trying to do things right at the first time and every time, rather than occasionally checking if they have gone wrong (Sallis, 2002 , p. 24). It can be thought as a philosophy of continual improvement which is only achievable by people. To improve quality and productivity, the driving force behind total quality management is a relentless daily hunt for opportunities. The concept of total quality improvement means getting every student in an institution to continually and aggressively evaluate how every subject, every system, and every program can be improved. 
Total quality management is based on the participation of all members of an organization and an institution in improving processes. In education, total quality management is one of the most important issues and it recognizes that it is the problem with today`s education system.

The students are unprepared to meet the demands of society when they are leaving or graduating from high schools and colleges. Those students are products of an education system that do not focus on quality and increased in social welfare cost.

There is a multidimensional concept of quality in vocational high schools, which includes all related functions and activities from the part of society and academic life in an institution. Therefore, any framework for assessment of quality should be taken into account, such as the quality of teachers, quality of administration and school services, infrastructure and facilities provided to students, student support services and human resources.

The impact of teacher competencies plays an important role in student academic achievement. In 2007, the Ministry of National Education of Indonesia initiated Teacher Certification Program, designed to improve as well as standardize the teacher quality in Indonesia. This program was established to respond to the facts that teachers' quality in Indonesia is far below the standard. The government of Indonesia chooses education as one of the highest priorities in its developmental strategy. By having a good quality of education, it is expected that Indonesian future generation will be able to cope with the challenges of development to ensure the welfare, progress and prosperity of the Nation. Teacher quality improvement program is an important strategy to improve the quality of education. Based on the previous study, it is found that one standard deviation increased in teacher quality is associated with a 0.1 to 0.2 standard deviation increased in student academic achievement.

UNESCO classifies Indonesia as a Nation with a moderate level of student achievement (Hapsariputri, 2010, p. 2).
Statistics reported by the Ministry of Education from comparative international test evidence confirm this (Triyanto, 2012, p. 867).

The quality of teacher plays a crucial role in determining a Nation's competitiveness, especially in the globalization era. Indonesia, in particular, has acknowledged the importance of improving the quality of education, especially the quality of teachers, in order to supply the country with high competitive human resources. Sixty five percent of the total number of 2.7 million teachers in Indonesia had not met the requirement as a professional teacher, so that a genius strategy is needed to produce a professional teacher in order to fill up the local and national or even international teacher. It can be done if societies and governments work together to achieve an improvement in the quality of teacher. If one accepts the premise that the quality of teachers produces the quality of students, then the poor achievements of students can be attributed to the poor quality of teachers in Indonesia (Jalal et al., 2009, p. 7).

This indicates that there is a strong relation between the teacher competences and the student performances. What teachers have taught and applied in the classroom made an impact on the students' results. Even though the awareness of the importance of the quality of education, especially teachers, has been undertaken to improve it, Indonesian government has to concern about the students' standard of achievement. The poor achievement of students may reflect the lower quality of teachers in Indonesia. As Winataputra states, "The main problem in Indonesian education system is all about teacher, teacher, and teacher. Teacher has lower quality and professionalism" (Lampung Post, 2009). Statistics from the Ministry of National Education (MONE, 2008) indicates that teachers in Indonesia have relatively a lower level of academic qualification than those of neighboring nations. More than 60 percent of the total 2.78 million teachers have not reached the level of academic qualification of four-year bachelor degree (D4/S1). 
This statement is also strongly emphasized by (Baedhowi, 2008) that only 41.7 percent out of $1,143,000$ teachers reached bachelor degree (S1). Low educational level also means underpaid salary. This suggests that there is a lack of incentive for teacher to upgrade their academic qualifications.

One of the problems being faced by the Nation of Indonesia is the low quality of education in every level, including the quality of Human Resource Issues (HRI). United Nations Educational, Scientific, and Cultural Organization (UNESCO) report, which was released on Thursday, 29 November 2007, shows Indonesia's ranking in terms of education fell from 62 among 130 countries in the world. Clearly, the Education Development Index (EDI) of Indonesia is 0.935, which is under Malaysia (0.945) and Brunei Darussalam (0.965).

In vocational education, many quality problems are surrounding, such as the low quality of new management systems, the insufficient quality of infrastructures and facilities access, the quality of learning, teachers' professional quality and performance, the quality related to educational leadership and managerial support of parties related to education. Indeed, the low quality of graduates is coming from these weaknesses of the education quality component, including in management aspect.

Considering the matter of government in Indonesia about this case, the National Education Department implements the management model of total quality management in schools. Quality management is explicitly systematic planning and quality control of students in an institution (organization). To adopt the opinion of Holmes and McElwee (2006, p. 596), total quality management might be suitable for teaching and learning function, which is the core of a school. Total quality management offers a vehicle for schools and colleges to manage themselves effectively in a time of rapid change and retain a clear focus on the essential and dominant purpose of education (Rao, 2003, p. 4).
As a solution to choose the development, some of the benefits and advantages offered by a vocational high school as a major capital call for people to choose vocational education. The guarantee to absorb graduates into the world of work is given to the public. Vocational high schools must be able to guarantee every graduate to be able to work in various industries. One is the provision of Special Employment Exchanges in each vocational school. To establish cooperation in the framework of labor supply, the World of Business and the World of Industries are the partners of vocational high schools. Vocational high schools always give each of their students the opportunity to undertake industrial practice and training. This activity helps students understand well about the situation in the industrialized world. The Industrial Practice activities strengthen the vocational direction and goals that are preparing graduates to work in the industry.

Act No. 20 of 2003 about National Education System, section 50, paragraph 3, states that 'The government and/or the local government organize/s at least one education unit at each level of education to be improved into an international-based educational unit.' The intention to conduct such pioneering of school organizing effort is including increasing the quality of education.

Based on the Act No. 20 of 2003 (National Education System), education in Indonesia is defined as a planned effort to establish international school for improving quality and competitiveness study environment and education process so that the students may actively develop their own potential to gain the religious and spiritual level, consciousness, personality, behavior and creativity.

One factor in the success of vocational education is an absorption of graduate to the World of Industries. It is important to study the World Development Quality in the vocational high school as a means of improving the partnership that produces vocational relevance of education to the labor market. 
Government Regulation No. 19 of the National Education Standards concerning with the second part by the Local Government Management Standards article 59 says, 'Local Government annual work plan supported by prioritizing education programs increases the total quality management of education to the needs of the community'.

The problem that might be faced by the vocational high schools in the application of TQM is the insufficiencies of the graduates to enter the global market along with poor skills that are not appropriate to the need and the current evolution of technological enterprise. Those lacks of students' performance in work experience inhibit them to be capable to be hired after graduating. One of the causes that bring this problem out to the surface is the shortage of good-quality instructors to train them enough in their field of study. Moreover, the deficiencies of building capacity, nonconditioning of infrastructures and facilities access do not motivate pupils to study harder. This means that the improvement of quality management in vocational schools is very worthwhile in order to reach high potency of quality education that meets the standard of all national schools background. It is mostly found that something that still remained to retardate the education quality is the shortage of good performance of teacher in transmitting materials methodologically and pedagogically to the students. The insufficiencies of the theoretical and practical evaluation of examination system at schools are also included in the deficiency of education quality. In addition, the committeemen between schools and enterprises to strengthen students' experience in the field of work is not well ruined to be enough for their training; figuring out their obvious interaction this time. The last is the existence of different level of graduates from private and public vocational high schools generates the inequality of their skills in the world of work that fades their backgrounds in the society.

Unfortunately, the management quality of education $\mathrm{n}$ is not the realized case found in vocational high schools in Yogyakarta yet. Hence, the measurement to apply that quality well is still critical referring to the lack of total quality management in those high schools.

\section{Vocational Education}

The national education system of Indonesia is generally aimed at elevating the intellectual life of the nation and fully developing Indonesian people, i.e as people who are devoted to God, have knowledge and skills, are in good physical and spiritual health, are independent and fair, and feel responsible for their country and nation (Dinn Wahyudin, 21-23 July, 2008).

Vocational education starts in the senior secondary school (grade 10,11, 12 or 13). School leavers from the $12^{\text {th }}$ grade of vocational high schools become tradesmen, craftsmen and represent skilled worker. The curriculum of vocational secondary education was set forth by the Minister of Education and Culture in Act No. 20/2003 (EAS TVET Provider Network Workshop, Friday 16/2012, Melbourne, Autralia).

In accordance with the Law Number 20 Year 2003 on National Education System, curriculum development is done by referring to the National Education Standards, and curricula at all levels and types of education are developed by the principle of diversification in accordance with the educational unit, the potential of the area, and learners.

Further, in Government Regulation Number 19 Year 2005 on National Education Standards, the standards directly related to the curriculum are the Content Standard and Competency Standards, set in the Minister of National Education Degree No. 22 in 2006 on the Content Standards and Minister of National Education Degree No. 23 in 2006 on the Graduate Competency Standards and the Minister of National Education Degree No. 24 in 2006.

Based on the Content Standards and the Graduate Competency Standards and guidelines prepared by the Board of National Standard Education, then the Unit of Primary and Secondary Education is 
expected to develop Curriculum at Education Unit Level (Kurikulum Tingkat Satuan Pendidikan [KTSP]) based on the educational unit, the potential of the area and regional characteristics, social and cultural backgrounds, and learners.

Currently, in 2007, school based curriculum 'Kurikulum Tingkat Satuan Pendidikan (KTSP)' was launched, introduced and steeply implemented in all level of school including in secondary vocational schools. The objectives of vocational education are to prepare students to enter the labor force, to develop professional skills and to prepare students to choose a career, to install the ability to compete and develop indecently, and to foster a national workforce to meet the manpower needs of business and industry.

Vocational secondary school implements education programs according to the perceived present and future demands for employment types. The vocational secondary school curriculum program is envisioned to be completed in three to four years. The curriculum is divided into six groups: (1) the agricultural and forestry group, for occupations in certain areas such as agribusiness, agronomy, animal husbandry, fisheries, and agriculture production management; (2) the industrial technology group, offering professions in building construction, mining, marine engineering, graphics, textiles, informatics, and industrial instrumentation; (3) the business and management, finance and banking, trade, and secretarial work; (4) the community welfare group, targeting employment with social services, community health, and community development; (5) the tourism group, whose graduates move into hotel, catering, fashion, beauty occupations; (6) the arts and handicraft group, whose skills are focused on applied arts, and the handcraft industry (the World Congress on Teacher of Technology and Vocational Education, held in Indonesia University of Education, Bandung on 21-23 July, 2008).

The official name of vocational high schools in Indonesia is 'Sekolab Menengah Kejuruan' (SMK), which can be literally translated in English as Vocational Senior Secondary School (VSSS). The use of senior here, comes from the level of secondary education in which it is divided by junior secondary and senior secondary. Indonesia used to have vocational schools in junior secondary (grade 7-9), but from the year 1990 , vocational school is only available from senior secondary school or starts from grade 10 (Paryono, 2005, p. 48). Comparing on how VSSS is offered, Indonesia's system is similar to Thailand, Vietnam, Malaysia, Germany and Mexico in which they separate general and vocational school in secondary education level. Concerning when VSSS is offered, Indonesia's VSSS is similar to Thailand, Vietnam, Malaysia, UK, France and USA in which it is offered at the $10^{\text {th }}$ grade. The access to vocational education is varying from country to country. No model is applicable for all. Likewise, the reason behind the decision to impose such number of access is different.

The access to vocational education is categorized into three groups (Tilak, 2003, p. 680). The first group are countries with around $40 \%$ access to vocational education. Countries like Indonesia, India, Thailand, Korea and Israel are in this group. The second group are the countries with about 50\% access such as China, France, Denmark and Finland. The last or the group with the highest access to vocational education, about $75 \%$, is Czech Republic and Austria. Lately, Indonesian government had planned to expand access to vocational education to obtain a closer level with the last group (Education Statistic 2011, retrieved on March 2011).

According to Gray and Paryono (2004, pp. 22-26), there are five influencing factors that contribute in shaping vocational education development in every country. It is also applicable to the decision to increase or decrease the vocational education access. The five factors are government climate, physical environment, human capital, social climate, and economic status.

From the afore-mentioned description, it can be concluded that vocational school is a school in which students are taught the 
skills needed to perform a particular job. Traditionally, vocational high schools have not existed to further education in the sense of liberal arts, but rather to teach only job specific skills, and such schools have been better considered to be institutions devoted to training, not education.

\section{Method}

After accosted to the different concepts of the scientists of management about total quality management, it was realized that its extension sphere was reached not only to the schools administration but also in technology scientific schools. Hence, it brought us to represent in this chapter the use of quantitative research and approache descriptive using statistics methods to well describe the application and analysis of total quality management in the vocational high schools.

\section{Type of Research Design}

This research employed a descriptive design included surveys and fact-finding enquiries of different kinds. The major purpose of descriptive research is description of the state of affairs as it exists at present. In social science and business research, the term 'descriptive research studies' is used quite often. The main characteristic of this method is that the researcher has no control over the variables; he/ she can only report what has happened or what happened. This research used descriptive studies in which the researchers sought to measure some items, for example, Mean, SD, preferences of people, or similar data (Kothari, 2009, pp. 34). This research was categorized as descriptive research that described to explore all factor about total quality management at vocational high schools, the events gone to look for the presence or absence of role between the variables under study in which in this case was the role of information between students and teachers variables. In this research, the approach used was a quantitative approach.

Arikunto (2006, p. 12) provides an overview of quantitative research as follows: "Quantitative research, as the name suggests, much is required to use numbers, ranging from data collection, interpretation of data, as well as the appearance of the result". Based on this explanation, in this study, the data to be interpreted were in the form of numbers. The data were obtained from the research instrument, i.e. a questionnaire. This research described quantitative research as explaining phenomena by collecting primary data which are analyzed using mathematically and statically based methods. The indicators were obtained from the research instrument, i.e. a questionnaire.

\section{Place of Research}

This study was conducted in five public and five private vocational high schools in Yogyakarta City that are majoring in business administration and technology about total quality management, comparing both private schools and public schools. In the schools, the total quality management was implemented.

Cluster sampling involves randomly selecting groups, not individuals. It was softened impossible to obtain a list of individuals which make up a target population. Subjects were then selected at random, to keep the same opportunities in order as a whole, since the selection of students and teachers used proportional cluster random sampling technique (Isaac and Michael, 1995).

Time of Research

This study included seven phases, namely preparation of proposals, seminar of proposals, implementation of research, processing and analysis of data, oral examination, thesis revision and research seminar. The research was carried out in the beginning of February until the end of June 2013.

\section{Population and Research Sample}

The population of the study was all teachers and students involved in five public and five private vocational high schools in the city of Yogyakarta that had already implemented the total quality management. The public vocational high schools consisted of: SMK1, SMK 2, SMK3, SMK 5, and SMKN 7, and the private vocational high 
schools consisted of: SMK Muhammadiyah 1, SMK Muhammadiyah 3, SMK BOPKRI 1, SMK PIRI 1, and SMK Perindustrian vocational high schools.

\section{Findings and Discussion}

Comparison of TQM in Public and Private Vocational High Schools

Description of descriptive findings show the differences in the implementation of total quality management intentions in public and private vocational high schools. The evaluation of the significance of the findings have been made by the researcher using a t-test statistic. Before the test is done, some tests were conducted to determine to use of the data distribution statistics parametric t-test, and have been analyzed to ensure homogeneity of variance to the two schools that have comparable variants for comparition.

\section{Discussion}

The measurement of total quality management in vocational high schools include five aspects: 1) Infrastructures and facilities access, 2) quality of improvement, 3) quality of teachers, 4) quality of examination system and 5) academic background of the teachers in vocational high schools. The five aspects of the application obviously require resources that are not small, and the implementation also requires continuous support for total quality management but it is not a static device, rather, it is a management mechanism that is always inherent in the educational process.

Total quality management in the view of the previous explanation requires a minimum condition that can be run, for example, to implement total quality management on the first aspect (infrastructures and facilities access), it deals with necessary infrastructure such as website presence online and e-learning, classroom conditions, training aids, building, books, technology tools, and other tangible forms. Schools must be able to provide these means that the first aspect of total quality management can be applied.
Public vocational high schools are funded by the government on a periodic basis, whereby one can be the allocation for purposes of total quality management, so there is no serious obstacles in delivering physical means. However, for private vocational high schools that do not receive fund on a periodic basis like public vocational high schools do, the fulfillment of physical facilities for the purposes of total quality management implementation has clearly become an obstacle that is not easily overcome. The difference in the characteristics is funding the implications for the ability to meet the minimum requirements for implementing total quality management. Total quality management is a general explanation of the causes of differences in the ability of application of total quality management between public and private vocational high schools.

Generaly, public vocational high schools include vocational technical nowadays has greatly developed, it is funding as a problem in the above example is not found again in private vocational high schools that successfully blend between schools as mandated by the constitution as a business school in education. The existence of private vocational high schools which was later named favorite school is the fact that reflects the ability of management to overcome funding problems. This fact also shows that there is no single explanatory ability of the application of total quality management to the difference between public and private vocational high schools.

Improvisation or innovation management as practiced in the private vocational high schools "favorites" can be implemented when government policy supports it. The statuses of public vocational high schools teachers are civil servants who earn salaries and pensions, on the other hand, private vocational high schools with teachers who do not receive decent salaries and pensions are issues that require completion from government policy. These things show that the difference in the incidence rate of application of total quality management in the public and private vocational high 
schools is closely related to government policies.

Explanatory mentoring which is performed by other stakeholders on the incidence of total quality management implementation differences, aspects of quality improvement, quality of teachers, quality of examination system, and academic background of teachers in vocational high schools is very difficult to manage when private vocational high schools do not get enough assistance by the stakeholders (Government) . These aspects are bound by the laws and regulations in its implementation on vocational high schools. Continuous assistance may simply be required for schools to increase the application of total quality management.

\section{Conclusions, Implication and Recommendation}

The description of the research finding is presented and concluded in this chapter; the conclusion, implication and suggestion is made in order to describe the performance of the total quality management in vocational high schools in Yogyakarta which leads to the description and exploration of the total quality management in public and private vocational high schools.

\section{Conclusion}

After analyzing the data, the conclusions obtained from the research are as follows:

First, the implementation of total quality management process worked well with:

The results of the above analysis is the fact (findings) field on the implementation of total quality management in the public and private vocational high schools. These findings may answer the questions posed in this study:

Infrastructure and facilities access of total quality management in public vocational high schools $(\overline{\mathrm{x}}=3,177)$ and private $(\overline{\mathrm{x}}=$ $2,998)$ are equally good. It is relative because teachers and students 'do not feel' the infrastructure and facilities access at other schools, and it could be about to change after comparing assessment.
The quality of improvement in public vocational high schools $(\bar{x}=3,341)$ is better than in the private sector $(\bar{x}=3.125)$.

The quality of teachers in public vocational high schools $(\bar{x}=3,382)$ is better than in the private sector $(\bar{x}=3,076)$.

The quality of examination system in public vocational high school $(\overline{\mathrm{x}}=3,429)$ is better than in the private sector $(\bar{x}=3,225)$.

Teachers' academic background in public vocational high schools $(\bar{x}=3,342)$ is better than in the private sector $(\overline{\mathrm{x}}=3.160)$.

The infrastructure and facilities are quite good and easy fact, including the building and laboratories process in the vocational high schools and teachers have understood the material presented.

The above result is very important to note for vocational high schools, stakeholders, and especially for government education office. The implementation of total quality management by vocational high schools is a joint achievement of which to be grateful, as well it should be because there is a difference between the ability to apply it in public and private vocational high schools. The results of the analysis categorize the Silverback high of total quality management implementation in private vocational high schools, and very high in the public vocational high schools. The differences are evident from the results of the test statistic and analysis data, the overall of total quality management as well as it is including aspects. Comparing the score of total quality management in public and private vocational high schools, it has found that public vocational high schools have more potency and have the highest means of quality than the private vocational high schools that have the lowest score of means of total quality management. If we also compared the whole means of the infrastructures and facilities access, quality of improvement, quality of teachers, quality of examination system, academic background of teachers in public vocational high schools and private vocational high schools, we found that the public vocational high schools possess the highest mean of those qualities than the private vocational high schools. It means that 
public vocational high schools have more potency and they are more advanced in using total quality management than the private vocational high schools.

The analysis reveals that, the new management systems of education in public and private vocational high schools are improving and developing, but private vocational high schools are still below the quality level of the public vocational high schools. It is also shown that the teachers' performance appraisals and the students' skills in the public ones are higher than in private vocational high schools; it implies that the examination system in public vocational high schools is more well-ordered than in private vocational high schools. Thus, there is a balance between the vocational high schools as an arm of the government that should be subject to be even regulated in detail with particular private vocational high schools freedom to formulate and achieve organizational targets. In order to improve the management system in teaching-learning factory smoothly, it requires support from all related parties, from teachers of production courses who would implement education system of producing industrial products, from the headmasters who would undertake the system of implementation strategies that consist of: empowering professional teachers to create industrial atmosphere in schools, supporting professional teachers to create marketable orders that can be executed by the students, motivating production course teachers to develop students` academic, vocational education personal and social competences.

The development of total quality management implementation in public vocational high schools are already advanced and it is more significant to enhance students' performance than in private vocational high schools; teachers' academic background are also very critical and among the rules required to be hired in vocational high schools. Hence, they are qualified enough and could easily adjust with the technology tools in teaching; more qualified teachers were found in public vocational high schools.
Based on all these results, it is concluded that total quality management is implemented by public vocational high schools and private vocational high schools in Yogyakarta. The application levels differ significantly $(\mathrm{t}$-value $=9,204, \quad \mathrm{p}$-value $=$ $<0.0001$ ), where the public vocational high schools are able to implement a very good level, while private vocational high schools are able to implement a good level.

The differences in the application of total quality management occurs in all measurable aspects: Infrastructures and facilities access, improvement quality, teachers quality, examination system quality, and teachers' academic background in vocational high schools. Specifically, on the aspects of infrastructures and facilities access, although on average significantly differ between public and private vocational high schools, the categories in the same level are high, and interpreting their differences are not too large.

\section{Implication}

Based on the conclusion, implications based on the problems faced by vocational high schools in creating student's life skills can be arranged. The implication is closely related to the importance of total quality management including infrastructures and facilities access, quality of improvement, quality of teachers, quality of examination system and teachers' academic background in vocational high schools.

Total quality management is basically a general term that can be said to apply to all management processes including schools. Total quality management in vocational high schools is an effort that can be conducted by the school in order to be qualified. Thus, the implementation of total quality management in private vocational high schools needs to be improved not only as an implication of the conclusion. It is a necessity, including for the public vocational high schools that have already performed well.

Vocational high schools have good management that is more likely to have good quality students. In contrast, schools that have insufficient management will also have 
an impact on the insufficiency of the students' quality as well. The goal of quality management is to develop a culture of total commitment to quality process in vocational high schools to prevent wastage.

School collaboration is needed to manifest the total quality management goal. Collaboration is defined as a form of unity of some people who make a formal institute with validity and accountability to allocate resource to reach specific-purpose altogether. Collaboration is molded if each party has the same aim and motivation. Schools performing good collaborations tend to have better students quality.

Vocational high schools as educational institutions are regulated by some borders such as rule bound and Government Regulation Act. Therefore, to improve the implementation of total quality management, there must be a pro-active government, either through regulations or laws. TQM also needs to be arranged so that teachers and students can access in any school, especially in fellow vocational high schools.

Suggestion

The above conclusion is very important to note for vocational high schools, stakeholders, and especially for government education office. The implementation of total quality management by vocational high schools is a joint achievement to be grateful, as it should be, because there is a difference in the application ability between public and private vocational high schools.

Normatively, the researcher recommended for public vocational high schools to maintain the performance to the application of total quality management that has been run, and for private vocational high schools to try improve it. Especially, private vocational schools need to be more proactive with stakeholders. It is a relevant problem, since it will be difficult to implement total quality management maximally if private vocational high schools do not actively perform improvisation.

Nowadays, it seems that the government encourages the decentralization of vocational high schools to develop themselves, but such condition is only a limited role as executive regulations. This impression needs the government's attention through the education department, and it is expected to continue to be examined to gain a maximum shared understanding so that private vocational high schools have the 'freedom' without violating any law or government rules about existing education. Thus, there is a balance between vocational high schools as an arm of government that should be subject to be regulated in detail with particular private vocational high schools freedom to formulate and achieve organizational targets.

Nonetheless, school commitees are increasing synergic relationships with national community. Then, International Industry, particularly community involvement in determining school policy by conducting consultation on the community through each school's commitees, will produce a school policy, and the consultation may be in the form of a hearing or consolidation.

In fact, vocational high schools system needs to improve a teaching-learning factory smoothly. It requires support from all related parties, from teachers of production courses who would implement management education system of producing industrial products, headmasters who would undertake the system of implementation strategies that consist of: empowering professional teachers to create industrial atmosphere in vocational high schools, supporting professional teachers to create marketable orders that can be undertaken by students, motivating production course teachers to develop students 'academic, vocational high schools personal and social competences.

Although the result of the research finding suggests that there is good total quality management, in order to enhance its quality at vocational high schools that lead to be excellent in providing good quality of vocational education to students, the researcher would like to share several recommendation as follows:

First, improving school environment to better direction is important so that it can 
manifest the school citizen's everyday behavior, by providing insight and understanding of the imporatance of good school culture as self-discipline, environemental care, responsibility, hardwork, for students through counseling or by making a contest which assesses the students about the school culture.

Second, increasing cooperation between citizens of the school, business, and governement to achieve vocational high schools' mission and vision is also crucial. It can be done more effectively by available forums, such as regular meetings, letters and other instructions.

\section{References}

Arikunto, S. (2006). Prosedur penelitian: Suatu pendekatan praktike [Research procedure: A practical approach]. Jakarta: Rineka Cipta.

Baedhowi. (2008). Strategi Peningkatan Kualitas dan Kompetensi Guru [Strategy of teachers' quality and competences improvement]. Direktorat Jenderal Peningkatan Mutu Pendidik dan Tenaga Kependidikan Departemen. Jakarta: Pendidikan Nasional.

Creswell, J. W. (2012). Educational research planning, conducting and evaluating quantitative and qualitative research. California: Sage Publishers, Inc.

Departemen Pendidikan Nasional Indonesia. (2003). Peraturan Menteri Nasional Republik Indonesia nomor 20 tabun 2003 tentang Sistem Pendidikan Nasional (UUSPN/20/2003) Pasal 50, Ayat 3 [The regulation of the National Ministry of Indonesian Republic no. 2 year 2003 about National Education System article 50, paragraph 3]. Jakarta: Depdiknas.

Departemen Pendidikan Nasional Indonesia. (2005). Education Statistics 2011. Journal Tends International Mathematics Science Study (TIMSS) 2011. Retrieved on March 2011. Jakarta: Education
Quality and Accountability Office (EQAO).

Direktorat Pembinaan SMK. (2008). Vocational school development program 2008. Jakarta: Directorate of Senior Vocational School Ministry of National Education.

Education Minister of Indonesia. (2006). Kurikulum Tingkat Satuan Pendidikan (KTSP) jenjang SMK [Curriculum at Education Unit Level at Vocational High School]. Jakarta: BSNP.

Federal Government experience. (1992). How to get started implementing total quality management. Total quality management handbook. Washington, D. C: Federal Quality Institute.

Isaac, S. \& Michael, W. B. (1995). Handbook in research and evaluation: For educators and behavioral science ( $2^{\text {nd }}$ ed.). San Diego, California: Edits Publishers.

Khotari, C. R. (2004). Research methodology: Methods and techniques ( $2^{\text {nd }}$ ed.). New Delhi: New Age International.

Minister of Education and Culture. Act No. 20/2003. International Journal of conference EAS TVET Provider Network Workshop, $\quad$ Friday 16/2012. Melbourne, Autralia: TVET Provider Network Workshop.

Minister of National Education Degree No. 22, No. 23 and No. 24. (2006). Kurikulum Tingkat Satuan Pendidikan (KTSP) 2007 [Curriculum at Education Unit Level 2007]. Jakarta: Depdiknas.

Peers, I. S. (2006). Statistical analysis for education \& psychology researchers. Bristol, UK: USA The Falmer Press.

Sallis, E. (2002). Total quality management in education ( $3^{\text {rd }}$ ed.). Virginia, USA: Quicksilver Drive Sterling.

Umaedi. (2000). Manajemen peningkatan mutu berbasis sekolab: Dinamika pendidikan [School-based quality improvement management: Education dynamics]. Dikmenum, dirjen Dikdasmen. Jakarta: Depdikbud. 